\title{
PROTOCOLO PARA A EMBRIOGÊNESE SOMÁTICA DO MAMOEIRO'1
}

\author{
ELIANE PIRES DE ALMEIDA², ROBERTO PEDROSO DE OLIVEIRA ${ }^{3}$ e JORGE LUIZ LOYOLA DANTAS ${ }^{4}$
}

RESUMO - O presente trabalho teve por objetivo estabelecer um protocolo de embriogênese somática para o mamoeiro (Carica papaya L.) cv. Baixinho de Santa Amália, grupo Solo. Foram utilizados quatro tipos de explantes e duas condições de cultivo, sendo as fases de indução de calos, indução e maturação de embriões somáticos, alongamento e enraizamento das plântulas avaliadas em diferentes meios de cultura. A combinação explante hipocótilo com folhas cotiledonares e meio de cultura $1 / 2 \mathrm{MS}+$ $10 \mathrm{mg} \mathrm{L}^{-1}$ de 2,4-D, sob condições de escuro, foi a mais favorável para a indução de calos friáveis. Os meios de cultura HMH com $0,2 \mathrm{mg} \mathrm{L}^{-1}$ de ANA e $2,0 \mathrm{mg} \mathrm{L}^{-1}$ de cinetina e $1 / 2 \mathrm{MS}$ foram adequados para a indução e maturação de embriões somáticos; o meio MS com $1 \mathrm{mg} \mathrm{L}^{-1} \mathrm{de} \mathrm{GA}_{3}$ foi adequado para o alongamento das plântulas; e o meio MS com $1 \mathrm{mg} \mathrm{L}^{-1} \mathrm{IBA}$, para o enraizamento. A eficiência das fases de indução de calos, indução de embriões, maturação de embriões, alongamento, enraizamento e aclimatação das plântulas foi de $100 \%, 98 \%, 44 \%, 42 \%, 50 \%$ e $80 \%$, respectivamente. O protocolo estabelecido possibilita que o processo de embriogênese somática seja realizado em um período de 230 dias, com uma eficiência final de 7\%, e pode ser utilizado em trabalhos de transformação genética do mamoeiro.

Termos para indexação: explante, calo, embrião somático, desenvolvimento embrionário, plântula, cotilédone.

\section{PAPAYA SOMATIC EMBRYOGENIC PROTOCOL}

\begin{abstract}
The objective of this work was to establish a protocol for somatic embryogenesis of papaya (Carica papaya L.) cv. Baixinho de Santa Amália, Solo group. Four explants and two culture conditions were used. The phases of callus induction, somatic embryo induction and development, elongation and rooting were evaluated in different culture media. The combination among hypocotyl with cotyledonal leaves, $1 / 2 \mathrm{MS}$ medium with $10 \mathrm{mg} \mathrm{L}^{-1} 2.4-\mathrm{D}$ and dark conditions was the best to induce friable calli. $\mathrm{HMH}$ medium with $0.2 \mathrm{mg} \mathrm{L}^{-1}$ ANA and $2.0 \mathrm{mg} \mathrm{L}^{-1}$ kinetin and $1 / 2 \mathrm{MS}$ medium were suitable to induce and to develop somatic embryos. MS medium with $1 \mathrm{mg} \mathrm{L}^{-1} \mathrm{GA}_{3}$ was the best to elongate the plantlets and MS medium with $1 \mathrm{mg} \mathrm{L}^{-1} \mathrm{IBA}$ to root them. The efficiency of callus induction, embryo induction, embryo development, elongation, rooting and acclimatization phases were $100 \%, 98 \%, 44 \%, 42 \%, 50 \%$ and $80 \%$, respectively. The somatic embryogenic protocol enables the process to be done in 230 days with final efficiency of $7 \%$. This protocol can be used in papaya genetic transformation.
\end{abstract}

Index terms: explants, callus, somatic embryo, embryonic development, seedlings, cotyledons.

\footnotetext{
${ }^{1}$ Aceito para publicação em 11 de janeiro de 2000. Extraído da dissertação de mestrado, apresentada pelo primeiro autor à Universidade Federal da Bahia (UFBA), Cruz das Almas, BA.

${ }^{2}$ Eng. Agrôn., M.Sc., EA, UFBA, Caixa Postal 82, CEP 44380-000 Cruz das Almas, BA.

E-mail: grama@gd.com.br

${ }^{3}$ Eng. Agrôn., M.Sc., Embrapa-Centro de Pesquisa Agropecuária de Clima Temperado (CPACT), Caixa Postal 403, CEP 96001-970 Pelotas, RS. E-mail: rpedroso@cena.usp.br

${ }^{4}$ Eng. Agrôn., D.Sc., Embrapa-Centro Nacional de Pesquisa de Mandioca e Fruticultura, Caixa Postal 007, CEP 44380-000 Cruz das Almas, BA. E-mail: loyola@ cnpmf.embrapa.br
}

\section{INTRODUÇÃO}

O mamoeiro (Carica papaya L.) é uma das fruteiras mais cultivadas e consumidas nas regiões tropicais e subtropicais do mundo, sendo o Brasil o maior produtor, com 1,65 milhão de toneladas (FAO..., 1996). As cultivares de mamoeiro mais utilizadas no país são Sunrise Solo, Improved Sunrise Solo line 72/12 e Tainung no 1 . Ultimamente, alguns agricultores têm utilizado a cultivar Baixinho de Santa Amália, resultante de uma mutação da cultivar 
Sunrise Solo, que apresenta menor porte como principal vantagem e polpa mais mole como desvantagem.

O desenvolvimento da cultura tem sido limitado por fatores relacionados à natureza dióica, heterozigose, à suscetibilidade a doenças e à falta de métodos comerciais de multiplicação vegetativa (Rajeevan \& Pandey, 1986). A doença causada pelo vírus-da-mancha-anelar-do-mamão (PRV) representa um dos maiores problemas fitossanitários para a cultura, no mundo, sendo responsável, no Brasil, pelo deslocamento dos plantios em direção a áreas nãoinfestadas (Medina et al., 1989).

Nas últimas décadas, diversas técnicas de biotecnologia têm sido empregadas com sucesso em apoio a programas de melhoramento do mamoeiro, tais como resgate de embriões, cultura de anteras, isolamento e cultivo de protoplastos, produção de sementes artificiais, micropropagação, marcadores moleculares e transformação genética (Oliveira et al., 1996).

Tratando-se do cultivo in vitro de tecidos de mamoeiro, diversos fatores têm sido observados afetando o sistema, tais como o sexo, clone, idade da planta, época de coleta dos explantes, tipo de explante, infecções sistêmicas, além de fatores relacionados à composição do meio de cultivo e às condições de cultura (Litz \& Conover, 1981; Oliveira et al., 1996). Uma das grandes limitações da cultura de tecidos consiste na necessidade de ajustes no balanço de nutrientes, reguladores de crescimento e condições de cultura para cada cultivar maximizar o seu desenvolvimento in vitro (Arora \& Singh, 1978).

O estabelecimento de um protocolo de embriogênese somática é importante por permitir a multiplicação massal de mudas hermafroditas de mamoeiro e condições para que seja realizada a transformação genética por via biolística, visando principalmente à resistência ao vírus-da-mancha-anelar.

Em várias cultivares de mamoeiro, embriões somáticos têm sido induzidos a partir dos explantes pecíolo, caule, folhas, raízes e embriões zigóticos, sendo, em seguida, regeneradas plântulas (Chen et al., 1987; Fitch \& Manshardt, 1990; Yang \& Ye, 1992; Fitch, 1993; Khatoon \& Sultana, 1994; Mondal et al., 1994).
O objetivo deste trabalho foi estabelecer um protocolo de embriogênese somática para o mamoeiro (Carica papaya L.) cv. Baixinho de Santa Amália, que possa ser aplicável aos materiais do grupo Solo.

\section{MATERIAL E MÉTODOS}

Os explantes iniciais do mamoeiro foram obtidos de plântulas germinadas in vitro. Para a germinação foram utilizados três frutos hermafroditas maduros provenientes de plantas do Banco de Germoplasma de Mamão da Embrapa-Centro Nacional de Pesquisa de Mandioca e Fruticultura. A desinfestação dos frutos foi realizada em condição asséptica, em solução de álcool $70 \%$ por dois minutos, solução comercial de hipoclorito de sódio $2 \%$ por 15 minutos, sendo, em seguida, lavados com água destilada esterilizada por três vezes. A sarcotesta das sementes foi removida em câmara de fluxo laminar; sendo o restante de cada semente disposto em tubo de ensaio $(25 \mathrm{~mm} \times 150 \mathrm{~mm})$ sobre meio de cultura MS (Murashige \& Skoog, 1962) suplementado com $500 \mathrm{mg} \mathrm{L}^{-1}$ de extrato de malte, e pH ajustado para 5,7. A germinação ocorreu em sala de crescimento no escuro e com a temperatura de $25 \pm 2^{\circ} \mathrm{C}$.

Para a indução de calos foram utilizados os explantes: a) hipocótilo com folhas cotiledonares totalmente expandidas com $15 \mathrm{~mm}$ de comprimento; b) folhas cotiledonares sem a nervura central; c) epicótilo (3 mm); d) secção de hipocótilo $(5 \mathrm{~mm})$, coletados, em média, 20 dias após a semeadura. Os explantes foram introduzidos individualmente em frascos $(3,5 \mathrm{~cm} \times 7,5 \mathrm{~cm})$ contendo $15 \mathrm{~mL}$ dos meios de cultura: a) 1/2MS suplementado com $2 \mathrm{mg} \mathrm{L}^{-1} \mathrm{de}$ 2,4-D (ácido diclorofenoxiacético), $60 \mathrm{~g} \mathrm{~L}^{-1}$ de sacarose, $50 \mathrm{mg} \mathrm{L}^{-1}$ de meso-inositol, $2 \mathrm{mg} \mathrm{L}^{-1}$ de glicina, $0,5 \mathrm{mg} \mathrm{L}^{-1}$ de ácido nicotínico, $0,5 \mathrm{mg} \mathrm{L}^{-1}$ de piridoxina, $0,4 \mathrm{mg} \mathrm{L}^{-1}$ de tiamina, $400 \mathrm{mg} \mathrm{L}^{-1}$ de glutamina, $10 \mathrm{~g} \mathrm{~L}^{-1}$ de ágar, pH 5,7; b) 1/2MS suplementado com $10 \mathrm{mg} \mathrm{L}^{-1} \mathrm{de}$ 2,4-D, $60 \mathrm{~g} \mathrm{~L}^{-1}$ de sacarose, $50 \mathrm{mg} \mathrm{L}^{-1}$ de meso-inositol, $2 \mathrm{mg} \mathrm{L}^{-1}$ de glicina, $0,5 \mathrm{mg} \mathrm{L}^{-1}$ de ácido nicotínico, $0,5 \mathrm{mg} \mathrm{L}^{-1}$ de piridoxina, $0,4 \mathrm{mg} \mathrm{L}^{-1}$ de tiamina, $400 \mathrm{mg} \mathrm{L}^{-1}$ de glutamina, $10 \mathrm{~g} \mathrm{~L}^{-1}$ de ágar, $\mathrm{pH} 5,7$; c) meio HMH (Alloufa, 1993) suplementado com $41 \mathrm{~g} \mathrm{~L}^{-1} \mathrm{de}$ sacarose, $0,18 \mathrm{mg} \mathrm{L}^{-1}$ de AIA (ácido indolacético), $0,20 \mathrm{mg} \mathrm{L}^{-1}$ de AIB (ácido indolbutírico), $0,19 \mathrm{mg} \mathrm{L}^{-1} \mathrm{de}$ ANA (ácido naftaleno acético), 0,22 $\mathrm{mg} \mathrm{L}^{-1}$ de 2,4-D, $0,21 \mathrm{mg} \mathrm{L}^{-1}$ de cinetina e $0,23 \mathrm{mg} \mathrm{L}^{-1}$ de BAP (benzilaminopurina), $\mathrm{pH}$ 6,5. Utilizaram-se condições de cultivo no escuro e sob luz (fotoperíodo de 16 horas e intensidade luminosa de 1.500 lux), em temperatura de $25 \pm 2^{\circ} \mathrm{C}$. O experimento foi inteiramente casualizado, contendo 24 tratamentos com 10 repetições cada um, constituindo um fatorial $4 \times 3 \times 2$ (quatro tipos de explante, três 
meios de cultura e duas condições de cultivo). Foram realizadas avaliações visuais da indução e crescimento dos calos a cada cinco dias por 30 dias.

Para a obtenção de embriões somáticos, metade dos calos induzidos em cada meio de cultura foi introduzida no meio $1 / 2 \mathrm{MS}$ sem os reguladores de crescimento e a outra metade, no meio $\mathrm{HMH}$ com $0,2 \mathrm{mg} \mathrm{L}^{-1}$ de ANA e 2,0 $\mathrm{mg} \mathrm{L}^{-1}$ de cinetina, sendo cultivados nas condições de escuro e de luz (fotoperíodo de 16 horas e intensidade luminosa de 1.500 lux), à temperatura de $25 \pm 2^{\circ} \mathrm{C}$, por dois recultivos, com passagens de quatro semanas. Foram realizadas avaliações mensais com relação à indução e maturação dos embriões.

Para avaliação do alongamento das plântulas de mamoeiro, novos embriões somáticos foram induzidos e maturados na combinação meios de cultura $1 / 2 \mathrm{MS}$ com $10 \mathrm{mg} \mathrm{L}^{-1}$ de 2,4-D e 1/2MS, no escuro. Em seguida, as plântulas regeneradas foram individualizadas e avaliadas em três meios de cultura: a) MS com 1,0 $\mathrm{mg} \mathrm{L}^{-1}$ de $\mathrm{GA}_{3}$; b) MS com 1,0 $\mathrm{mg} \mathrm{L}^{-1}$ de CIN e $0,05 \mathrm{mg} \mathrm{L}^{-1}$ de ANA; c) MS com $0,23 \mathrm{mg} \mathrm{L}^{-1}$ de BAP, $0,19 \mathrm{mg} \mathrm{L}^{-1}$ de ANA e $1,0 \mathrm{mg} \mathrm{L}^{-1}$ de $\mathrm{GA}_{3}$, por um período de 30 dias, sendo cultivados em fotoperíodo de 16 horas, 1.500 lux e temperatura de $25 \pm 2^{\circ} \mathrm{C}$. Foram utilizadas 50 repetições por tratamento e consideradas alongadas as plântulas com tamanho superior a $5 \mathrm{~mm}$.

O enraizamento das plântulas foi avaliado nos meios de cultura MS com 1,0 mg L-1 de IBA, MS com 2,0 $\mathrm{mg} \mathrm{L}^{-1}$ de IBA e MS com 3,0 $\mathrm{mg} \mathrm{L}^{-1}$ de IBA, sempre com a suplementação de $1,0 \mathrm{mg} \mathrm{L}^{-1}$ de riboflavina. A avaliação foi realizada após um período de 30 dias, nas mesmas condições de cultivo do experimento anterior, sendo utilizadas 20 plântulas com tamanho superior a $5 \mathrm{~mm}$ por tratamento, e realizado um corte de $1 \mathrm{~mm}$ da base das mesmas antes da introdução in vitro.

A aclimatação foi realizada transplantando-se as plântulas em copos de plástico de $300 \mathrm{~mL}$ contendo substrato estéril à base de vermiculita, areia e matéria orgânica (1:1:1), sendo, inicialmente, mantidas sob condições de câmara úmida, temperatura de $27 \pm 4{ }^{\circ} \mathrm{C}$ e fotoperíodo de 16 horas. Em seguida, foi realizada a redução gradual da umidade do ambiente de aclimatação.

\section{RESULTADOS E DISCUSSÃO}

A porcentagem de contaminação dos explantes foi variável em razão da fase da cultura in vitro, com médias de $4 \%$ durante as fases de indução de calos e de embriões somáticos, $30 \%$ durante a germinação dos embriões somáticos, $10 \%$ na multiplicação, $15 \%$ no alongamento e $5 \%$ no enraizamento das plântulas, sendo a maior parte das contaminações causada por bactérias, provavelmente de natureza endógena. A contaminação endofítica em tecidos de mamoeiro é bastante comum (Drew \& Smith, 1986; Rajeevan \& Pandey, 1986; Winnaar, 1988). A utilização de explantes provenientes de plântulas germinadas in vitro (Chen et al., 1987; Yamamoto \& Tabata, 1989) não foi suficiente para contornar os níveis de contaminação; portanto, em trabalhos posteriores, devem ser adicionados antibióticos ao meio de cultura, conforme recomendam Reuveni et al. (1990).

Em geral, os calos friáveis obtidos a partir dos quatro tipos de explantes estudados apresentaram coloração amarelo-pálida, sendo maiores os de hipocótilo com folhas cotiledonares, havendo, neste caso, a formação de calos a partir do ponto de inserção das folhas cotiledonares com o hipocótilo. A formação de calos iniciou-se de três a cinco dias após a introdução do explante no meio de cultura, e o máximo crescimento foi atingido aos 20 dias.

A análise da melhor combinação explante $\mathrm{x}$ meio de cultura $\mathrm{x}$ fotoperíodo permite observar que em vários casos ocorreu $100 \%$ de indução de calos (Tabela 1), mas quando foi analisada a porcentagem de calos friáveis, houve $100 \%$ de indução apenas nas combinações hipocótilo com folhas cotiledonares em meio $1 / 2 \mathrm{MS}$ com $10 \mathrm{mg} \mathrm{L}^{-1}$ de 2,4-D e folha cotiledonar em meio de cultura $1 / 2 \mathrm{MS}$ com $2 \mathrm{mg} \mathrm{L}^{-1}$ de 2,4-D, ambos mantidos no escuro (Tabela 2). Souza Júnior (1994) já havia relatado a alta eficiência do explante hipocótilo com folhas cotiledonares para a indução de calos embriogênicos. No meio de cultura $\mathrm{HMH}$, os calos obtidos foram de maior tamanho, apresentando, no entanto, menor friabilidade. Neste meio de cultura, Alloufa (1993), trabalhando com embriões zigóticos, obteve indução de calos superior a $60 \%$, porém estes calos eram altamente embriogênicos. Em geral, os calos mantidos no escuro apresentaram maior crescimento do que os mantidos em fotoperíodo de 16 horas, concordando, assim, com os resultados obtidos por Winnaar (1987).

A indução de embriões somáticos ocorreu por meio de um processo de embriogênese indireta, e somente a partir de calos dos explantes hipocótilo com folhas cotiledonares e folha cotiledonar. $\mathrm{O}$ cultivo no escuro também apresentou os melhores resultados (Tabela 3). 
A diferenciação dos calos formando embriões somáticos ocorreu em sua superfície. Ao longo de dois subcultivos de 30 dias houve formação de 0 a 30 embriões somáticos por calo. Os embriões eram inicialmente globulares, passando, em seguida, para as formas cordiforme, torpedo e cotiledonar. Num mesmo calo embriogênico pôde-se observar embriões em estágios distintos. Os embriões cotiledonares formaram pequenas plântulas (<2 mm). Fitch (1993) obteve resultados semelhantes, ou seja, dois a 20 embriões somáticos após três semanas, ao trabalhar com hipocótilos das cultivares Kapoho, Sunset, Sunrise e Waimanalo.

Houve grande variação na indução de embriões em diferentes combinações de meio de cultura, fotoperíodo e explante (Tabela 3). Essas variações de respostas in vitro demonstram que para cada explante existe uma melhor combinação de meio de cultura e fotoperíodo para a obtenção de embriões somáticos. A porcentagem máxima de indução de embriões somáticos obtida $(60 \%)$ foi superior à obtida por Fitch (1993), que após seis semanas de cul-

TABELA 1. Porcentagem de indução de calos de explantes de mamoeiro (Carica papaya L.) cv. Baixinho de Santa Amália em diferentes meios de cultura e fotoperíodos, aos 20 dias de cultivo ${ }^{1}$.

\begin{tabular}{|c|c|c|c|c|}
\hline \multirow[t]{2}{*}{ Explante } & \multirow{2}{*}{$\begin{array}{l}\text { Fotoperíodo } \\
\text { (claro/escuro) }\end{array}$} & \multicolumn{3}{|c|}{ Meio de cultura } \\
\hline & & $1 / 2 \mathrm{MS}+10 \mathrm{mg} \mathrm{L}^{-1}$ de $2,4-\mathrm{D}$ & $1 / 2 \mathrm{MS}+2 \mathrm{mg} \mathrm{L}^{-1}$ de $2,4-\mathrm{D}$ & HMH \\
\hline $\begin{array}{l}\text { Hipocótilo com folhas } \\
\text { cotiledonares }\end{array}$ & $16 / 8$ & 90Aa & $100 \mathrm{Aa}$ & $100 \mathrm{Aa}$ \\
\hline Folha cotiledonar & & $0 \mathrm{Ab}$ & $0 \mathrm{Ab}$ & $0 \mathrm{Ab}$ \\
\hline Hipocótilo & & 30Bab & $100 \mathrm{Aa}$ & $100 \mathrm{Aa}$ \\
\hline Epicótilo & & $0 \mathrm{Ab}$ & 40Aab & $0 \mathrm{Ab}$ \\
\hline $\begin{array}{l}\text { Hipocótilo com folhas } \\
\text { cotiledonares }\end{array}$ & $0 / 24$ & 100Aa & $100 \mathrm{Aa}$ & $100 \mathrm{Aa}$ \\
\hline Folha cotiledonar & & $60 \mathrm{ABa}$ & $100 \mathrm{Aa}$ & $\mathrm{OBb}$ \\
\hline Hipocótilo & & $80 \mathrm{Aa}$ & $100 \mathrm{Aa}$ & $100 \mathrm{Aa}$ \\
\hline Epicótilo & & 90Aa & $90 \mathrm{Aa}$ & $100 \mathrm{Aa}$ \\
\hline
\end{tabular}

TABELA 2. Porcentagem de indução de calos friáveis de explantes de mamoeiro (Carica papaya L.) cv. Baixinho de Santa Amália, em diferentes meios de cultura e fotoperíodos, aos 20 dias de cultivo².

\begin{tabular}{|c|c|c|c|c|}
\hline \multirow[t]{2}{*}{ Explante } & \multirow{2}{*}{$\begin{array}{l}\text { Fotoperíodo } \\
\text { (claro/escuro) }\end{array}$} & \multicolumn{3}{|c|}{ Meio de cultura } \\
\hline & & $1 / 2 \mathrm{MS}+10 \mathrm{mg} \mathrm{L}^{-1}$ de $2,4-\mathrm{D}$ & $1 / 2 \mathrm{MS}+2 \mathrm{mg} \mathrm{L}^{-1}$ de $2,4-\mathrm{D}$ & HMH \\
\hline $\begin{array}{l}\text { Hipocótilo com folhas } \\
\text { cotiledonares }\end{array}$ & $16 / 8$ & $90 \mathrm{Aa}$ & $60 \mathrm{Aa}$ & $30 \mathrm{Ab}$ \\
\hline Folha cotiledonar & & $\mathrm{OAb}$ & OAa & $0 \mathrm{Ab}$ \\
\hline Hipocótilo & & $30 \mathrm{Aab}$ & 30Aa & 70Aa \\
\hline Epicótilo & & $\mathrm{OBb}$ & $40 \mathrm{Aa}$ & $\mathrm{OBb}$ \\
\hline $\begin{array}{l}\text { Hipocótilo com folhas } \\
\text { cotiledonares }\end{array}$ & $0 / 24$ & $100 \mathrm{Aa}$ & $90 \mathrm{Aa}$ & $90 \mathrm{Aa}$ \\
\hline Folha cotiledonar & & $60 \mathrm{ABa}$ & $100 \mathrm{Aa}$ & $\mathrm{OBb}$ \\
\hline Hipocótilo & & 80Aa & $\mathrm{OBb}$ & $60 \mathrm{ABab}$ \\
\hline Epicótilo & & $70 \mathrm{Aa}$ & $80 \mathrm{Aa}$ & $\mathrm{OBb}$ \\
\hline
\end{tabular}

${ }^{1}$ Médias seguidas pela mesma letra maiúscula na linha e minúscula na coluna não diferem significativamente, a 5\% de probabilidade pelo teste nãoparamétrico de Kruskal-Wallis. 
TABELA 3. Porcentagem de indução de embriões somáticos em mamoeiro (Carica papaya L.) cv. Baixinho de Santa Amália introduzidos em diferentes combinações de meios de cultura.

\begin{tabular}{lcrrrrrr}
\hline Explante & Fotoperíodo & \multicolumn{6}{c}{ Meio indução calos/meio indução embriões } \\
\cline { 2 - 7 } & (claro/escuro) & $1 / 4$ & $1 / 5$ & $2 / 4$ & $2 / 5$ & $3 / 4$ & $3 / 5$ \\
\hline Hipocótilo com & $16 / 8$ & 0 & 60 & 0 & 0 & 0 & 0 \\
folhas cotiledonares & $0 / 24$ & 60 & 0 & 0 & 0 & 0 & 0 \\
Folha cotiledonar & $16 / 8$ & 0 & 0 & 0 & 0 & 0 & 0 \\
& $0 / 24$ & 20 & 60 & 20 & 60 & 0 & 0 \\
Hipocótilo & $16 / 8$ & 0 & 0 & 0 & 0 & 0 & 0 \\
& $0 / 24$ & 0 & 0 & 0 & 0 & 0 & 0 \\
Epicótilo & $16 / 8$ & 0 & 0 & 0 & 0 & 0 & 0 \\
& $0 / 24$ & 0 & 0 & 0 & 0 & 0 & 0 \\
\hline
\end{tabular}

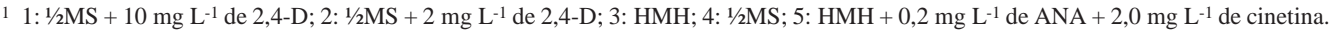

tivo em meio $1 / 2 \mathrm{MS}$ com 2,4-D obteve $45 \%$ de embriogênese utilizando embriões zigóticos como explantes iniciais. Os meios de cultura $\mathrm{HMH}$ com $0,2 \mathrm{mg} \mathrm{L}^{-1}$ de ANA e 2,0 $\mathrm{mg} \mathrm{L}^{-1}$ de cinetina e $1 / 2 \mathrm{MS}$ mostraram-se adequados para a indução de embriões.

Foram obtidas mais de uma centena de plântulas, que se multiplicaram rapidamente à taxa média de três por subcultivo de 30 dias. Mondal et al. (1994) obtiveram taxa de multiplicação de 6,8 brotos a cada 15 dias nesta fase, utilizando segmentos de raízes como explante inicial para a formação de calos. As plântulas obtidas apresentaram folhas minúsculas, a maioria delas normais, alongamento reduzido ( $<2 \mathrm{~mm}$ ), não enraizando mesmo em meio de cultura com altas concentrações de $\operatorname{AIB}\left(0,5\right.$ a 5,0 mg L $\left.\mathrm{m}^{-1}\right)$. Fitch (1993), embora tenha obtido elevada eficiência no processo de embriogênese, regenerou plântulas predominantemente anormais. Litz (1986) destaca que plântulas de mamoeiro derivadas de calo têm apresentado considerável grau de anomalias, tais como policotiledonia, fasciação e falha no crescimento internodal. Tais anomalias também foram observadas nas plântulas regeneradas.

$\mathrm{O}$ alongamento das plântulas foi mais eficiente no meio de cultura MS com $1 \mathrm{mg} \mathrm{L}^{-1}$ de $\mathrm{GA}_{3}$ (Tabela 4). As plântulas apresentaram altura média de 7,60 mm aos 60 dias, ausência de multiplicação, a maioria das folhas com desenvolvimento normal e baixa porcentagem de formação de calos na base dos explantes (26\%), concordando com os resultados obtidos por Winnaar (1988). Os meios MS com
TABELA 4. Alongamento de plântulas de mamoeiro (Carica papaya L.) cv. Baixinho de Santa Amália introduzidas em diferentes meios de cultura ${ }^{1}$.

\begin{tabular}{lcc}
\hline Meio de cultura $^{2}$ & $\begin{array}{c}\text { Altura média } \\
\text { das plântulas } \\
(\mathrm{mm})\end{array}$ & $\begin{array}{c}\text { Formação de calo } \\
\text { na base dos } \\
\text { explantes }(\%)\end{array}$ \\
\hline MS+GA & $7,60 \mathrm{a}$ & 26 \\
MS+CIN+ANA & $5,53 \mathrm{~b}$ & 83 \\
MS+BAP+ANA+GA & $2,40 \mathrm{c}$ & 96 \\
\hline
\end{tabular}

${ }^{1}$ Médias seguidas pela mesma letra na coluna não diferem significativamente, a $5 \%$ de probabilidade pelo teste de Tukey.

$2 \mathrm{MS}+\mathrm{GA}_{3}\left(1,0 \mathrm{mg} \mathrm{L}^{-1}\right) ; \mathrm{MS}+\mathrm{CIN}\left(1,0 \mathrm{mg} \mathrm{L}^{-1}\right)+\mathrm{ANA}\left(0,05 \mathrm{mg} \mathrm{L}^{-1}\right)$ $\mathrm{MS}+\operatorname{BAP}\left(0,23 \mathrm{mg} \mathrm{L}^{-1}\right)+\operatorname{ANA}\left(0,19 \mathrm{mg} \mathrm{L}^{-1}\right)+\mathrm{GA}_{3}\left(1,0 \mathrm{mg} \mathrm{L}^{-1}\right)$.

$1 \mathrm{mg} \mathrm{L}^{-1}$ de CIN e $0,05 \mathrm{mg} \mathrm{L}^{-1}$ de ANA e MS com $0,23 \mathrm{mg} \mathrm{L}^{-1}$ de BAP, $0,19 \mathrm{mg} \mathrm{L}^{-1}$ de ANA e $1,0 \mathrm{mg} \mathrm{L}^{-1}$ de $\mathrm{GA}_{3}$ recomendados, respectivamente, por Reuveni et al. (1990) e Chowdhury (1991), apresentaram resultados inferiores. A fase de alongamento é essencial para o enraizamento das plântulas, uma vez que plântulas menores do que $5 \mathrm{~mm}$ e maiores do que $10 \mathrm{~mm}$ dificilmente enraízam (Miller \& Drew, 1990).

$\mathrm{Na}$ Tabela 5 verifica-se que o enraizamento foi mais eficiente no meio de cultura MS com $1 \mathrm{mg} \mathrm{L}^{-1}$ de IBA $(50 \%)$, apresentando em média 2,75 raízes por plântula e comprimento médio de $1,50 \mathrm{~cm}$, associado a pequena proporção de formação de raízes anormais e melhor desenvolvimento da parte aérea. As raízes formadas eram na maioria das vezes normais e com geotropismo positivo, com diâmetro em 
TABELA 5. Enraizamento de plântulas de mamoeiro (Carica papaya L.) cv. Baixinho de Santa Amália introduzidas em diferentes meios de cultura ${ }^{1}$.

\begin{tabular}{lccc}
\hline Meio de cultura & Enraizamento (\%) & Número de raízes/plântula & $\begin{array}{c}\text { Comprimento } \\
\text { das raízes }(\mathrm{cm})\end{array}$ \\
\hline MS+IBA $\left(1,0 \mathrm{mg} \mathrm{L}^{-1}\right)$ & $53,33 \mathrm{a}$ & $2,75 \mathrm{a}$ & $1,50 \mathrm{a}$ \\
MS+IBA $\left(2,0 \mathrm{mg} \mathrm{L}^{-1}\right)$ & $13,33 \mathrm{~b}$ & $1,00 \mathrm{a}$ & $1,25 \mathrm{a}$ \\
MS+IBA $\left(3,0 \mathrm{mg} \mathrm{L}^{-1}\right)$ & $6,67 \mathrm{~b}$ & $2,00 \mathrm{a}$ & $2,00 \mathrm{a}$ \\
\hline
\end{tabular}

${ }^{1}$ Médias seguidas pela mesma letra na coluna não diferem significativamente, a 5\% de probabilidade pelo teste de Tukey.

torno de $1 \mathrm{~mm}$ e com pelo menos quatro raízes adventícias. Esses resultados estão de acordo com os obtidos por Rahaman et al. (1992), Islan et al. (1993) e Vianna (1996). Porcentagens superiores de enraizamento (> 85\%) foram obtidas por Reuveni et al. (1990) e Drew (1988), utilizando plântulas com três a cinco folhas e crescimento ativo da parte aérea.

$A$ adição de riboflavina ao meio de cultura foi importante por atuar fotooxidando o IBA (Drew et al., 1991), uma vez que, embora o IBA seja muito eficiente na indução de raízes, pode atuar retardando o desenvolvimento delas (Drew, 1988).

A sobrevivência das plântulas normais durante o processo de aclimatação foi de $80 \%$, variando em virtude da qualidade da parte aérea e raízes das plântulas. Rajeevan \& Pandey (1986) obtiveram resultados semelhantes, utilizando o mesmo substrato.

A eficiência do protocolo de embriogênese somática foi de $7 \%$, requerendo um período de 230 dias (Tabela 6). Yang \& Ye (1992) obtiveram eficiência de $36 \%$ no processo, após 240 dias e utilizando pecíolos como explante inicial. Estes autores obtiveram $94 \%$ de eficiência na fase de desenvolvimento dos embriões que resultaram em plântulas de melhor qualidade maximizando as etapas posteriores. Porém, como foram obtidas dezenas de embriões somáticos de cada calo na fase da indução, a eficiência de $44 \%$ consiste em um valor relevante. Trabalhos posteriores visando aumentar a eficiência de cada etapa do processo de embriogênese somática e reduzir os níveis de contaminação podem ser realizados visando maximizar o sistema proposto.

O protocolo proposto foi utilizado com sucesso na embriogênese somática da cultivar de mamoeiro Sunrise Solo, apresentando resultados bastante semelhantes aos obtidos com a cv. Baixinho de Santa Amália, provavelmente pelo fato de as cultivares per-
TABELA 6. Eficiência do protocolo de embriogênese somática em mamoeiro (Carica papaya $\mathrm{L}$.) cv. Baixinho de Santa Amália.

\begin{tabular}{lccc}
\hline Fase do processo & \multicolumn{2}{c}{$\begin{array}{c}\text { Período Efic. de cada } \\
\text { (dias) }\end{array}$} & $\begin{array}{c}\text { Efic. do } \\
\text { fase }(\%)\end{array}$ \\
processo (\%) \\
\hline Indução de calos & 20 & 100 & 100 \\
Indução de embriões & 60 & 98 & 98 \\
Desenvolvimento embriões & 30 & 44 & 43 \\
Alongamento & 60 & 42 & 18 \\
Enraizamento & 30 & 50 & 9 \\
Aclimatação & 30 & 80 & 7 \\
\hline
\end{tabular}

tencerem ao mesmo grupo Solo. Portanto, espera-se que o protocolo possa ser utilizado também para outros materiais do grupo Solo.

\section{CONCLUSÕES}

1. As combinações de $1 / 2 \mathrm{MS}$ com $10 \mathrm{mg} \mathrm{L}^{-1}$ de 2,4-D e de HMH com 0,2 $\mathrm{mg} \mathrm{L}^{-1}$ de ANA e 2,0 mg L-1 de cinetina ou $1 / 2 \mathrm{MS}$, ambas na ausência de luz, são as mais adequadas à embriogênese somática a partir de hipocótilo com folhas cotiledonares de mamoeiro cv. Baixinho de Santa Amália.

2. O meio MS com $1 \mathrm{mg} \mathrm{L}^{-1}$ de $\mathrm{GA}_{3}$ é o mais adequado para o alongamento e o meio MS com $1 \mathrm{mg} \mathrm{L}^{-1}$ IBA para o enraizamento das plântulas.

3. O protocolo estabelecido possibilita que o processo de embriogênese somática seja realizado em um período de 230 dias, com eficiência total de $7 \%$, e pode ser utilizado em trabalhos de transformação genética do mamoeiro.

\section{REFERÊNCIAS}

ALLOUFA, M.A.I. Effect of some growth regulators on embryo culture of Carica papaya L. in vitro. Revis- 
ta Brasileira de Fruticultura, Brasília, v.15, n.3, p.27-32, 1993.

ARORA, I.K.; SINGH, R.N. Growth hormones and in vitro callus formation of papaya. Scientia Horticulturae, Amsterdam, v.8, p.357-361, 1978.

CHEN, M.H.; WANG, P.J.; MAEDA, E. Somatic embryogenesis and plant regeneration in Carica papaya L. tissue culture derived from root explants. Plant Cell Reports, Berlin, v.6, p.348-351, 1987.

CHOWDHURY, A.R. Propagation of papaya through tissue culture. Annals of Bangladesh Agriculture, Dacca, v.1, n.1, p.45-46, 1991.

DREW, R.A. Rapid clonal propagation of papaya in vitro from mature field-grown trees. HortScience, Alexandria, v.23, n.3, p.609-611, 1988.

DREW, R.A.; SIMPSON, B.W.; OSBORNE, W.J. Degradation of exogenous indole-3-butyric acid and riboflavin and their influence on rooting response of papaya in vitro. Plant Cell, Tissue and Organ Culture, Dordrecht, v.26, p.29-34, 1991.

DREW, R.A.; SMITH, N.G. Growth of apical and lateral buds of papaw (Carica papaya L.) as affected by nutritional and hormonal factors. Journal of Horticultural Science, Ashford, v.61, n.4, p.535543, 1986

FAO QUARTERLY BULLETIN OF STATISTICS. Rome, v.9, n.3/4, 1996. 144p.

FITCH, M.M.M. High frequency somatic embryogenesis and plant regeneration from papaya hypocotyl callus. Plant Cell, Tissue and Organ Culture, Dordrecht, v.32, p.205-212, 1993.

FITCH, M.M.M.; MANSHARDT, R.M. Somatic embryogenesis and plant regeneration from immature zygotic embryos of papaya (Carica papaya L.). Plant Cell Reports, Berlin, v.9, p.320-324, 1990.

ISLAN, R.; RAHMAN, S.M.; HOSSAIN, M.; JOARDER, O.I. In vitro clonal propagation of papaya (Carica papaya L.). Pakistan Journal of Botany, Karachi, v.25, n.2, p.189-192, 1993.

KHATOON, K.; SULTANA, R. Plant regeneration from Carica papaya cv. Malir grown in tissue culture. Pakistan Journal of Botany, Karachi, v.26, n.1, p.191-195, 1994.
LITZ, R.E. Papaya (Carica papaya L.) In: BAJAJ, Y.P.S. (Ed.). Biotechnology in agriculture and forestry trees. Berlin : Springer, 1986. v.1, p.220-232.

LITZ, R.E.; CONOVER, R.A. Effect of sex type, season and other factors on in vitro establishment and culture of Carica papaya L. explants. American Society for Horticultural Science Journal, Alexandria, v.106, n.6, p.792-794, 1981.

MEDINA, J.C.; BLEINROTH, E.W.; SIGRIST, J.M.M.; MARTIN, Z.J.; NISIDA, A.L.A.C.; BALDINI, V.L.S.; LEITE, R.S.S.F.; GARCIA, A.E.B. Mamão: cultura, matéria-prima, processamento e aspectos econômicos. 2.ed. Campinas : Instituto de Tecnologia de Alimentos, 1989. 367p.

MILLER, R.M.; DREW, R.A. Effect of explant type on proliferation of Carica papaya L. in vitro. Plant Cell, Tissue and Organ Culture, Dordrecht, v.21, n.1, p.39-44, 1990.

MONDAL, M.; GUPTA, S.; MUKHERJEE, B.B. Callus culture and plantlet production in Carica papaya (var. Honey Dew). Plant Cell Reports, Berlin, v.13, p.390-393, 1994.

MURASHIGE, T.; SKOOG, F. A revised medium for rapid growth and bioassays with tobacco tissue culture. Physiologia Plantarum, Copenhagen, v.15, p.437497, 1962.

OLIVEIRA, R.P.; DANTAS, J.L.L.; ALMEIDA, E.P.; NICKEL, O.; VILARINHOS, A.D.; MORALES, C.F.G. Uso da biotecnologia no melhoramento genético e propagação do mamoeiro. In: MENDES, L.G.; DANTAS, J.L.L.; MORALES, C.F.G. (Ed.). Mamão no Brasil. Cruz das Almas : UFBA/ Embrapa-CNPMF, 1996. 179p.

RAHAMAN, S.M.; HOSSAIN, M.; JOARDER, O.I.; ISLAM, R. Rapid clonal propagation of papaya through culture of shoot apices. Indian Journal of Horticulture, Bangalore, v.49, n.1, p.18-22, 1992.

RAJEEVAN, M.S.; PANDEY, R.M. Economics of mass propagation of papaya through tissue culture. In: WITHERS, L.A.; ANDERSON, P.G. (Ed.). Plant tissue culture and its agricultural applications. London : Butterworths, 1986. p.211-215.

REUVENI, O.; SHLESINGER, D.R.; LAVI, U. In vitro clonal propagation of dioecious Carica papaya. Plant Cell, Tissue and Organ Culture, Dordrecht, v.20, p.41-46, 1990.

Pesq. agropec. bras., Brasília, v.35, n.10, p.2017-2024, out. 2000 
SOUZA JÚNIOR, M.T. Produção de plantas transgênicas de mamão resistentes ao vírus da mancha-anelar-do-mamoeiro (PRV): relatório final. Geneva, Estados Unidos : Cornell University, 1994. 95p.

VIANNA, G.R. Micropropagação do mamoeiro (Carica papaya $\mathrm{L}$.) utilizando ápices caulinares de plantas adultas. Viçosa : UFV, 1996. 65p. Dissertação de Mestrado.

WINNAAR, W. Clonal propagation of papaya in vitro. Plant Cell, Tissue and Organ Culture, Dordrecht, v.12, n.3, p.305-310, 1988 .
WINNAAR, W. First plants from papaw callus. Citrus and Subtropical Fruits Research Institute Information Bulletin, Johannesburg, n.177, p.1-2, 1987.

YAMAMOTO, H.; TABATA, M. Correlation of papaya and enzyme production with laticifer formation in somatic embryos of papaya. Plant Cell Reports, Berlin, v.8, p.251-254, 1989.

YANG, J.S.; YE, C.A. Plant regeneration from petioles of in vitro regenerated (Carica papaya L.) shoots. Academia Sinica Botanical Bulletin, Taipei, v.33, n.4, p.375-381, 1992. 